UDC 373(091)"1910/1914":070(477)

DOI: 10.24919/2519-058x.17.218182

\title{
Vitaliy VYZDRYK
}

PhD hab. (History), Associate Professor of the Department of Humanitarian Sciences, Institute for Moral and Psychological Support, Hetman Petro Sahaidachnyi National Army Academy, 32 Heroes of Maidan street, Lviv, Ukraine, postal code 79026 (v.vyzdryk05@gmail.com)

ORCID: 0000-0001-5427-5825

\section{Konstiantyn KURYLYSHYN}

PhD (History), Head of the Department of Ukrainian Studies of the Vasyl Stefanyk National Scientific Library of Ukraine in Lviv, 2, V. Stefanyk street, Lviv, Ukraine, postal code 79000 (kurylyshyn_k@ukr.net)

ORCID: 0000-0003-0104-7292

\section{Віталій ВИЗДРИК}

доктор історичних наук, дочент кафедри гуманітарних наук Інституту морально-психологічного забезпечення Національної академії сухопутних військ імені Петра Сагайдачного, вул. Героїв Майдану, 32, м. Львів, Украӥна, індекс 79026 (v.vyzdryk05@gmail.com)

\section{Костянтин КУРИЛИШИН}

кандидат історичних наук, завідувач відділу украӥніки Львівської начіональної наукової бібліотеки України ім. В. Стефаника, вул. В. Стефаника, 2, м. Львів, Україна, індекс79000 (kurylyshyn_k@ukr.net)

Bibliographic Description of the Article: Vyzdryk, V. \& Kurylyshyn, K. (2020). Ukrainian schooling before World War I (based on the "Dilo" magazine). Skhidnoievropeiskyi Istorychnyi Visnyk [East European Historical Bulletin], 17, 112-123. doi: 10.24919/2519-058x.17.218182

\section{UKRAINIAN SCHOOLING BEFORE WORLD WAR I (BASED ON THE "DILO" MAGAZINE)}

\begin{abstract}
The purpose of the article is to analyze the state of the Ukrainian schooling before World War I according to the magazine "Dilo" (1910 - 1914). The methodology of the research is based on the principles of objectivity and historicism, as well as general and special historical methods, which helped to reveal the importance of the national education in the struggle for the Ukrainian university and national schooling in pre-war Galicia (Halychyna). The scientific novelty is that for the first time an attempt has been made to highlight the Ukrainians'education system state before World War I, as the crucial factor in the cultural development of the Ukrainian ethnic group in the region, which contributed to the Ukrainians' national self-assertion in the struggle for the political rights. The Conclusions. The Ukrainian schooling issue was the part of the National Liberation Movement in western Ukraine in Austria-Hungary before World War I outbreak. In general, the Ukrainian component of the educational process in Galicia was characterized by the authorities' neglect of the Ukrainian language rights, which became one of the fundamental processes of the Polonization policy pursued by the local administrative apparatus. This approach manifested itself in schooling - the local officials made every
\end{abstract}


effort to circumvent the current legislation and oppose the Ukrainian primary education system to the Polish one. The Ukrainians' complicated condition was facilitated by the fact that the Utraquism was forced in secondary school and the struggle against the possibility of opening a Ukrainian university complemented the difficult picture for the Ukrainians, which was provided by the private educational institutions' establishment became the partial way out of the above-mentioned problem.

Key words: schooling, Ukrainian university, Ukrainian Pedagogical Society, national school unit "Ridna Shkola", Polonization policy.

\title{
УКРАЇНСЬКЕ ШКІЛЬНИЦТВО НАПЕРЕДОДНІ ПЕРШОЇ СВІТОВОЇ ВІЙНИ (ЗА МАТЕРІАЛАМИ ЧАСОПИСУ “ДІЛО”)
}

\begin{abstract}
Анотація. Метою статті с аналіз стану українського шкільництва напередодні Першої світової війни за матеріалами газети “Діло” (1910 - 1914 рр.). Методологія дослідження. Методологічною основою дослідження є поєднання принципів історизму та об'єктивності, дотримання загальнонаукових $i$ спеціально-історичних методів, щзо сприяло розкриттю значимості національної освіти у боротьбі за украӥнський університет та національне шкільництво у передвоєнній Галичині. Наукова новизна полягає у висвітленні стану системи освіти украӥнців напередодні Периої світової війни, як важливого чинника культурного розвитку українського етносу регіону, щзо сприяло національному самоствердженню украйнців y боротьбі за політичні права в період бездержавності. Висновки. Питання украӥнського икільництва було складовою національно-визвольного руху на західноукраӥнських землях в Австро-Угорщиині напередодні Першої світової війни. Загальна картина української складової освітнього процесу в Галичині характеризувалася нехтуванням владними інституціями правами української мови, щзо стало одним із засадничих процесів полонізаційної політики провадженої місиевим адміністративним апаратом. Такий підхід проявив себе у шкільництві - місиеві чиновники усіляко старалися обійти чинне законодавство і протиставити украйнській системі початкової освіти польську. Насадження утраквізму у середньому шкільниитві $і$ боротьба проти можливості відкриття украӥнського університету доповнювали складну для украйнців загальну картину, частковий вихід з якої забезпечило заснування приватних закладів освіти.

Ключові слова: шкільництво, украӥнський університет, Українське педагогічне товариство, Крайовий шкільний союз “Рідна школа”, полонізаційна політика.
\end{abstract}

The Problem Statement. The Ukrainian life daily presentation was depicted in the magazine "Dilo" during 1910 - 1914 was characterized by the struggle for the national identity, which was outlined by a wide range of requirements, for instance, the Ukrainian tables establishment in state institutions, the Ukrainian language observance in all spheres of life, a Ukrainian university grand-opening in Lviv, the electoral reform establishment and granting the Ukrainians autonomy within the Austro-Hungarian Empire. The abovementioned issues took place simultaneously with the European political situation aggravation and the Polish-Ukrainian relations, the Ukrainian-Moscofil confrontation, as well as the deepening of relations between the Ukrainians on both banks of the Zbruch River.

The Analysis of the Sources and Recent Researches. Numerous researchers focused on the history of Western Ukraine before World War I. The Ukrainian schooling formation in Western Ukraine, which was the part of the National Liberation Movement, become the scientific research object several times, written by the following authors: B. Stuparyk (Stuparyk, 1998) V. Stynska (Stynska, 2007), L. Vovk (Vovk, 2017 ), M. Barna (Barna, 2002), Z. Hipters (Hipters, 2006), I. Solyar, H. Sholota (Soliar \& Sholota, 2019), N. Fedchyshyn, T. Magsumov (Fedchyshyn \& Magsumov, 2019), K. Kurylyshyn (Kurylyshyn, 2015) and the others. The above-mentioned researchers reveal the schooling formation main stages in Ukraine from ancient times to the present, consider the creation and development of 
educational institutions of various types and the role of the Ukrainian intelligentsia in their formation.

A number of studies in the Polish historiography are devoted to the educational process subject in Galicia (Halychyna). Among them are the works written by the following scientists: J. Świeboda (Świeboda,1996), M. Stinia (Stinia, 2010), A. Meissner (Meissner, 2007), and R. Pelczar (Pelczar, 2015). Most researchers, used the statistical material when they covered the schooling in Galicia (Halychyna), were biased towards the Ukrainian education of the region.

According to the available literature, the above-mentioned topic is developed insufficiently and fragmentary. The magazine "Dilo" became the source base, which was the one and only Ukrainian magazine published daily in Galicia, which represented the interests of the stateless nation and became a powerful factor in the public opinion formation and growing the Ukrainians national consciousness. Due to the content's analysis, we have a golden opportunity to reproduce the daily events of the Ukrainian past during 1880 - 1939 in the smallest detail. Furthermore, the magazine "Dilo" is an important source for research in politics, church, school, cooperation, science, education, art in Galicia and throughout Ukraine.

The purpose of the article is to analyze the Ukrainian schooling condition and its role in the Galician Ukrainians national identity formation. We will pay attention to the public schooling problems, which was widely covered in the columns of the magazine "Dilo" during the prewar period and highlight the Galician elite struggle, the national youth, for the Ukrainian university establishment in Lviv.

The Statement of the Basic Material. The Ukrainian schooling became one of the main issues of the "Vichevyi Rykh" movement several times. On the $30^{\text {th }}$ of January in 1910, the "Viche Rusyniv mista Lvova" (Organization of Ruthenians of the City of Lviv), headed by Ye. Ozarkevych, held a "viche" dedicated to the public schooling problem, highlighting the Ukrainian schools' issue in Lviv (Viche Rusyniv mista Lvova, 1910). The National (Krayova) School Council was in charge of the schooling issues solution, as the division was made into Ukrainian and Polish as autonomous components, the public schools opening in communities where the number of the Ukrainian school-age children reached 40 people, the required number of the state teachers' seminaries and gymnasiums establishment., The suggestion was made to support the private Ukrainian educational institutions opening, until the requirements became a reality.

According to the National School Council reports, there was a gradual increase in both: the number of educational institutions and the number of students, who studied there. Hence, during 1909 - 1910 there was the following number of public schools in Galicia 5,198 3,345 single-grade, 1,192 two-grade, 24 three-grade, 362 four-grade, 131 five-grade, 53 sixgrade, 91 separate. The educational process for more than 1 million students was provided by 13829 teachers, 613 communities received state subsidies for the new schools' construction. The teachers' seminaries comprised of 17 state institutions - 14 men's and 3 women's. The education process was conducted in Polish in 8 of them, 9 were considered to be utraquistic. There were 54 public gymnasiums, 13 real schools, 13 private gymnasiums with the rights of public schools, which enrolled 35930 students, including more than 7000 Ukrainians in order to meet the secondary schooling needs (Halytske shkilnytstvo v shk. R. 1909/10, 1910).

In general, the picture of the Ukrainian component of the educational process in Galicia was characterized by Polonization phenomena introduced by the National School Council, which confirmed the following facts - the learning process in public schools was conducted in Polish with a small number of the Polish students, delay in transforming the 2nd-grade 
schools with the Ukrainian language as the language of instruction, classrooms, which enabled the continuation of studies in gymnasiums, the absence of the Ukrainian 5th and 6th grade educational institutions, referral to work in Ukrainian schools of Polish teachers, who did not speak Ukrainian, but instead there were official transfers of Ukrainian teachers to Western Galicia (Slidamy Kraievoi Rady Shkilnoi, 1912). The above-mentioned facts and similar ones of the biased attitude towards the Ukrainian school system were reflected in the rubric "Our School is under the Yoke".

Due to the conditions, there was the urgent need for the Galician Ukrainians to enroll children in national schools and preschools, public and private ownership. For example, in 1911, the "Organization of Ruthenians of the City of Lviv" ("Viche Rusyniv mista Lvova") invited Ukrainian families to indulge into the learning process at M. Shashkevych City 4-grade Public School for boys and girls (Skarbkivska Street, part 26), the Imperial Royal Men's Teacher's Seminary 4-grade Exercises School (Mokhnatskoho Street, part 8), the Imperial Royal Women's Teacher's Seminary 4-grade Exercises School (Sacramento Street, part 7), the Russian Women's Teacher's Seminary 4-grade Exercises School (Mokhnatsky Street, part 12), Borys Hrinchenko Public School (Dunina-Borkovskyi St., part 30), T. Shevchenko 5-grade Women's Special School (Mokhnatskoho St., part 12), the Russian Women's Teachers' Seminary (Mokhnatskoho St., part 12), the Imperial Royal Academic Gymnasium (Leva Sapihi St., Part 8), the Imperial Royal Academic Gymnasium branches (Teatralna Street, part 22), Men's Trade School (candidates' registration in the "Prosvita" society, Rynok, part 10). At M. Shashkevych Public School the student contingent consisted of the children, who came from the workers' and artisans' poorer Ukrainian families. In order to provide students with the necessary school supplies and clothing, the directorate turned to the national institutions and concerned citizens for help. One of the most complicated school's issues was the unsuitable premises for the educational process, which was called nothing more than the "old and smelly rudera". Diverse appeals to the city authorities to provide a new home for the school were in vain (Yak lvivska ruska hromada dbaie pro bidnu ditvoru shkoly imeny Markyiana Shashkevycha?, 1910); (Miska shkola im. Markiiana Shashkevycha u Lvovi, 1913).

B. Hrinchenko Private Public School history began at the beginning of 1910 - 1911, where 46 Ukrainian children ( 22 boys and 24 girls) were enrolled for in the first grade in Horodok suburb. The School Committee was established, headed by Professor V. Biletskyi, in order to ensure the functioning of the school. During the first school year, almost 4,5 thousand krons were collected for the school needs, and a thousand kron less was spent. In 1912 the Private School Committee made a decision on to build a separate educational building. The solemn dedication of the new premises took place on the $19^{\text {th }}$ of October in 1913, B. Hrinchenko Private 4-grade Public School was located in a separate two-story wing of the company "Dniester" buildings (Horodotska street, part 95 and part 97) (V pryvatnii narodnii shkoli im. Borysa Hrinchenka na horodetskim peredmistiu u Lvovi..., 1910). King Danylo Private School was the second private school in Zhovkva suburb of Lviv, where studies began in the fall of 1912 (Shkola im. korolia Danyla, nova ukrainska narodna shkola na zhovkivskim peredmistiu..., 1912). Kn. Lev Public School, the third private educational institution was planned to open in Lychakiv suburb on the $1^{\text {st }}$ of September in1914 (Narodna shkola im. kn. Lva, 1914).

According to the regional law issued on the 12 of June in 1907, two languages were used while providing some instructions during the teachers' training: the Polish and Ukrainian 
languages. Therefore, the National (Krayova) School Council demanded that the Ukrainian Private Women's Teachers' Seminary of the Russian (Ukrainian) Pedagogical Society (UPT) directorate switch to Utraquistism in order to acquire the "publicity right". The answer was unequivocal: "The Russian Pedagogical Society Department has always applied and applies the principle: to detain the purely Ukrainian character of the school, even if it comes to renounce the publicity right" (Proch z utrakvizmom! 1910).

The Ukrainians remained the only nation in the Austrian state that did not have a single state Teacher's Seminary. In 1912, the Ukrainian Pedagogical Society and the National (Krayovyi) School Union came up with the idea of founding Men's Private Teacher's Seminary, which was opened in September, 30 students were enrolled in the first year. The educational institution was located at the following address: Horodotska street, part 95 at the beginning of 1913 - 1914. Hence, two schools were situated in the same building: B. Hrinchenko Public School and Men's Private Teacher's Seminary (Pryvatnyi ukrainskyi muzheskyi uchytelskyi seminar u Lvovi, 1912).

In Kolomyia the private Ukrainian Women's Teacher's Seminary of the UPT began its educational process in November 1910. There were enrolled 122 students. At the same time, the local branch of the UPT opened a similar Men's Seminary (Pryvatna zhinocha semynaryia RPT in Kolomyia, 1912); (Ruskyi muzheskyi pryvatnyi seminar v Kolomyi, 1912). The Women's Teacher's Seminary, the private educational institution, was opened in Ternopil in 1913 - 1914 (Ternopil (Pryv. ukr. seminar uchytelskyi), 1913).

In 1911 there were 114 industrial and 17 trade schools in Galicia (Halychyna), none of which was Ukrainian. Inequality could also be seen in the students' division on the basis of nationality as there were no statistics on the Ukrainians (Fakhovi shkoly v Avstryi ta v Halychyni, 1912). The exception was the Ukrainian Trade School of the "Prosvita" society, where studies began in the autumn of 1911 under Professor R. Zalozetskyi's leadership (Ukrainska torhovelna shkola Tovarystva "Prosvita" u Lvovi, 1912). According to the magazine "Dilo", insufficient attention was paid to the peasant children's possibility to study in lower agricultural schools, which were funded by the state and provided pupils with a decent knowledge-base in order to form a good master. The story connected with Metropolitan A. Sheptytskyi's gift of 16 mortuaries of land with a courtyard building in Korshevo (near Kolomyia) to the "Silskomy Hospodariu" (The Farmer) in order to establish an agricultural school, turned out to be negative for the Ukrainians. As a result, society failed to start the establishment procedure of the educational institution for several years and tried to sell the land, which was donated by the metropolitan (Z Pokutia (Korshivska fakhova shkola i "Silskyi Hospodar"), 1914).

There were 8 Polish schools of housewives in order to provide agricultural education for girls. Despite the fact that they were founded mainly on private initiatives, their funding was based on subventions from local and state budgets. Understanding the importance of this issue for the Ukrainians led to the establishment by the "Prosvita" society of Women's Economy School in Uhertsy Vyniavski, Rudky Povit (county). The grand opening of the school took place on the 7th of November in 1912 (Shkoly zhinochoho hospodarstva v Halychyni, 1912). Furthermore, some magazine's publications concerned studies at the National (Krayova) Weaving School in Hlyniany, the Regional (Krayova) Pottery and Tile School in Kolomyia.

Taking everything into consideration, control over secondary education in Galicia (Halychyna) became a crucial factor in the future human resources formation of the local government. Hence, the Poles used all possible methods, including the fact that in 1867 the 
Polish language was introduced as the main language with the help of which the learning process had to be carried out at secondary schools, to slow down the process of creating a strong stratum of the Ukrainian intelligentsia. "This policy has, among the others, the purpose: to strengthen the position of the Poles as a nation that represents the state in Galicia, and as long as I can delay the arrival of the wave when the Ukrainian people become so strong that they can successfully start the struggle to be on their territory in Eastern Galicia, he represented the state" (Polska polityka v oblasty serednoho shkilnytstva, 1913).

The National (Krayova) School Council's educational policy often focused its efforts not on improving the quality of education, but on preventing the establishment of state Ukrainian gymnasiums so that the number of non-Polish gymnasium students did not exceed one third.

During 1910 - 1914, the magazine "Dilo" supported and popularized the development process of the Ukrainian secondary (public and private) schools actively, which opened its doors to students of various categories and contributed to the education of nationally conscious Ukrainian youth. In particular, the magazine reported on Ukrainian gymnasiums in Belz (private gymnasium, founded in 1912) (Nova ukrainska gimnazyia, 1912), Busk (M. Shashkevych private gymnasium, founded in 1910), with the publicity right, certificates' recognition by the state, (1914) (Pryvatna ukr. gimnazyi v Busku... oderzhala pravo pryliudnosty..., 1914), Vashkivtsi (private gymnasium, founded in 1912) (Ukrainska pryvatna realna gimnazyia na Bukovyni povstaie... u Vashkivtsiakh, 1912), Vyzhnytsia (state) Pro vyzhnytsku gimnazyiu, 1913), Hlyniany (private gymnasium course, founded in 1912) (Ukrainska gimnazyia v Hlynianakh, 1912), Horodentsi (T. Shevchenko private women's peasant gymnasium, founded in 1909, with the publicity right from 1911) (Z Horodenky (V spravi pryvatnoi ruskoi gimnazyi), 1910), founded in 1912 (Persha zhinocha selianska gimnazyia v Horodentsi, 1912), Dolyna (M. Shashkevych private gymnasium, founded in 1911, with the publicity right from 1913), (Dolynska ukrainska gimnazyia oderzhala pravo pryliudno sty na shk. r. 1913 / 14,1914), Drohobych (private gymnasium course, ceased to exist in 1914) (Na pryvatnu gimnazyiu v Drohobychy zlozhyly vid 1. XI. 1911 r. do 12.VII.1913 r. Dobrodii, 1913), Kitsmani (state, utraquist gymnasium) (Ts. k. derzhavna gimnazyia v Kitsmany, 1911), Kolomyia (state gymnasium) (Ruska gimnazyia v Kolomyi, 1912), Komarno (private gymnasium course, founded in 1911) (Ukrainskyi kurs gimnazyialnyi v Komarni, 1912), Kopychyntsi (private gymnasium, founded in 1908, with the publicity right since 1913), Zbarazhi (private gymnasium, founded in 1910, with the publicity right since 1913) (Pravo pryliudnosty, 1913), private female Bazilian sisters servants gymnasium with the publicity right) (Private women's gymnasium SS Vasylyianok in Lviv in r. 1910 / 11,1911), Przemyњl (state (Peremyska ruska gimnazyia in shk. r. 1909/10, 1910), private women's lyceum (Ruskyi Instytut dlia divchat in Peremyshly vede vid dovshykh lit zhinochyi litsei..., 1910)), Rohatyn (private with the right publicity) (Pravo pryliudnosty, 1914), Stanislav (state and women's private), Ternopil (state gymnasium), Turka (povit (county) state, utraquist gymnasium) (De-shcho iz statystyky gimnazyi, 1914), Chernivtsi (state, utraquist gymnasium) (Ukrainski gimnazyi na Bukovyni, 1912), Chortkiv (M. Shashkevych private gymnasium, founded in 1911, with the publicity right from 1913) (O gimnazyiu v Chortkovi, 1911), Yavoriv (private gymnasium, founded in 1907, with the publicity right from 1913) (Pravo pryliudnosty, 1913).

The Bursa educational institutions (institutes, orphanages) remained the inextricable part of the educational process organization, which provided the students' life outside of the school for a modest fee (for a certain percentage free of charge). The rubrics "Bursa Competitions", 
"Bursa and Institutes Competitions", "Education and school" were announced about the admission conditions. The newspaper's editorial board put emphasis on the importance of institutions and also covered problematic issues that required an appropriate response from the Ukrainian community. In particular, due to the insufficient funding of bursa institutions (institutes, boarding schools), there were unsuitable premises, poor nutrition, use of physical force against pupils by abbots or instructors. "Intelligent, ideological and moral education of youth" was the Men's Institute "Kobzar" priority (Lviv, Raya street, part 4) (Vykhovuiuchyi muzheskyi instytut "Kobzar"..., 1914).

The Ukrainian societies, which were responsible for organizing and supporting national schooling and teaching, were replenished with several structures. Thus, on the $9^{\text {th }}$ of February in1910, the National (Krayova) School Union "Ridna Shkola" (NSU) was established, which was supposed to promote the Ukrainian private public and secondary schools establishment. In mid-February, the NSU meeting passed resolutions requiring the authorities to ensure the Polish and Ukrainian secondary schools equal treatment, requiring the Ukrainian gymnasiums' establishment in povits (counties) with the Ukrainian population predominantly, and opposing joint Polish-Ukrainian gymnasiums under the joint leadership. The NSU depended on voluntary donations, which did not cover the necessary expenses from year to year, so in 1911 the idea of a "sotykovyi fund" was popularized. Due to the "sotykovyi fund", each Galician Ukrainian had to donate 1 "sotyk" everyday, which provided about 1 million Krons a month for the private schooling needs. Other projects were also discussed, for example, during $1912-1913$ the NSU took care of 11 private secondary schools, for the maintenance of which almost 163 thousand Krons were collected, but the expenditures on the private secondary schools exceeded 284 thousand Krons (Zaviazanie "fondu sotykovoho" u Lvovi, 1911).

In December 1913, the Regional Commission for the defense of Ukrainian schooling and Ukrainian teachers, headed by S. Baran, began its work. The Commission called to counteract the school polonization process, to create county structures, to document the facts of violations and to appeal them in a lawful manner, involving Ukrainian ambassadors (Proty polskoho pokhodu na nashe shkilnytstvo, 1914).

The "Shkilna Pomich" (the School Aid) Society in Lviv, which took care of the students, who studied at the city folk schools, continued its long history. During 1910 and 1911, the society spent 2,794 krons on food, clothing, shoes, and school supplies, and the poorest students' treatment. The institution's management stated that "nowadays, given the growing number of Russian children in public schools, both city and private, we must limit the scope of our activities exclusively to the public school, which brings together children of the poorest sections of Lviv population" ("Shkilna Pomich" u Lvovi, 1912).

The Russian Pedagogical Society (RPS), which was founded in 1881, began operating in parallel with the NSU in February in 1910. Their tasks, especially in the field of the private schooling, were often duplicated and not clearly differentiated. In February 1912, at the RPS general meeting amendments were adopted to the statute, which approved the name of the institution as the Ukrainian Pedagogical Society (UPS), and turned the branches into "circles" The UPS circle became an independent unit and was fully responsible for the maintenance of the Ukrainian school, the stock exchange, and the protection of its territory. The main branch of the society was reorganized into the "Circles Union" (Reorganizatsyia Ruskoho Tovarystva Pedagogichnoho, 1912).

The Ukrainian gymnasiums and universities establishment, measures to abolish Utraquism and the opening of separate Ukrainian and Polish educational institutions remained decisive 
in the of the secondary and higher schools Ukrainian Teachers Society activities of "Teacher's Community", founded in November 1908 and headed by M. Hrushevskyi. The most difficult educational problem was the struggle for the Ukrainian university establishment in Lviv, the cause of which was recognized as one of the most "burning issues of the cultural and sociopolitical life of the whole Ukraine" (Za ukrainskyi universytet, 1912).

In 1910, against the background of a positive government decision on the possibility of establishing an Italian law faculty in Vienna and renewing the efforts of the Poles to legislate the Polish character of Lviv University, the Ukrainians intensified their efforts to open the Ukrainian university in Lviv. Thus, on the $14^{\text {th }}$ of March in 1910, the Ukrainian students held a "viche" within the university premises under the slogan "Long live an independent Ukrainian university in Lviv". The reaction of "all-Polish" academic youth was predictable, their main aim was to defend the "Polishness" of Lviv University in any possible way (Demonstratsyia ukrainskykh studentiv u lvivskim universyteti, 1910).

The Polish-Ukrainian student confrontation intensified in May 1910 with the educational institution's Polish blockade outbreak and the Ukrainian students' obstruction in accessing the educational process. The Student Council passed a resolution on the $20^{\text {th }}$ of May in 1910, claiming that the blockade of the university by "all-Polish" students took place with the university's leadership tacit consent while calling on the Ukrainian public to fight together for a national university (Viche ukrainskoi molodizhy u Lvovi..., 1910).

The culmination of the Polish-Ukrainian confrontation took place on the $1^{\text {st }}$ of July in 1910, when the Ukrainian students gathered for another unauthorized Senate Viche in one of the university auditoriums. In response, the Polish students began blocking, building barricades. As a result, there was a clash with the use of weapons. A. Kotsko, a law student, was fatally wounded by one of the bullets. The Commission of Inquiry tried to shift the blame onto the Ukrainian students, 128 of whom were detained by police. On the same day, the Polish students walked the streets of Lviv beating windows and signs at the Ukrainian institutions. The outcome of the Polish evening Viche was the following: they recognized Professors M. Hrushevskyi and S. Dnistryanskyi as the Ukrainian radicalism ideological instigators and demanded their dismissal from the university (Vshekhpolskyi mord na universyteti, 1910).

The arrested students, as a result of these events, were released from the remand prison in September for trial. 101 Ukrainian students were charged with accusations but none of the Polish student was blamed. The "Trial 101" began in the premises of Lviv Regional Criminal Court on the $14^{\text {th }}$ of February in 1911 and was found exceptional in the chronicle of the Austrian judiciary (the mass political trials remained a characteristic feature of the Russian judicial system). All suspects were found guilty of public violence and imprisoned: 5 persons for three months, 68 - for a month, 26 - for 14 days, two students had to be trialed separately. Lawyers V. Okhrymovych and V. Starosolskyi appealed against the court decision, but the decision of the Cassation Tribunal upheld the verdict of the first instance. (Vyrok polskoho sudu na ukrainskykh studentiv, 1911); (Sprava pomyluvania obzhalovanykh v protsesi 101..., 1912).

The Conclusions. The general picture of the Ukrainian component of the educational process in Galicia was characterized by Polonization phenomena, which was supported by the National School Council. Special attention was paid to the Ukrainian public and private educational institutions of different levels. The Ukrainian societies were responsible for the national schooling organization and support and were replenished with new structures the National School Union "Ridna Shkola", the "Pomich Molodi (Youth Aid) Society, the Regional Commission for the defense of Ukrainian Schooling and Ukrainian Teachers. 
The culmination of the Polish-Ukrainian confrontation in the struggle for the Ukrainian university establishment was the murder of student A. Kotsk at the university. The consequence of these tragic events was a lawsuit against the Ukrainian students, which in the press was called the "Trial 101" (according to the number of defendants). As a result of many years of struggle, a draft imperial letter was adopted, which provided for the opening of the Ukrainian university by the $1^{\text {st }}$ of October in 1916 .

The authorities' neglected the Ukrainian language usage in the educational process became one of the basic acts of the Polonization policy pursued by the local administration. The planting of Utraquism in secondary schools and the struggle against the possibility of opening the Ukrainian university complemented the difficult overall picture for the Ukrainians, which made it difficult to establish private educational institutions. It should be noted that owing to the Galician Ukrainians education's system formation issue coverage on "Dilo" magazine pages gives us a splendid opportunity to a better and deeper understanding of its content.

Acknowledgements. We express a sincere gratitude to all the members of the editorial board for consultations provided during the preparation of the article for printing. Special thanks to Rector of Hetman Petro Sahaidachnyi National Army Academy for the support and to Director of the Vasyl Stefanyk National Scientific Library of Ukraine

Funding. The authors received no financial support for the research, authorship, and publication of this article.

\section{BIBLIOGRAPHY}

Barna, M. (2002). RozvytokpedahohichnoiosvityvHalychyni (1772 - 1939 rr.) [Development of teacher education in Galicia (1772 - 1939)]. Ridna shkola, 7-8, 33-48. [in Ukrainian]

De-shcho iz statystyky gimnazyi. (1914). De-shcho iz statystyky gimnazyi [Some of the high school statistics]. Dilo, 14 tsvitnia, 7. [in Ukrainian]

Demonstratsyia ukrainskykh studentiv u Ivivskim universyteti. (1910). Demonstratsyia ukrainskykh studentiv u lvivskim universyteti [Demonstration of Ukrainian students at Lviv University]. Dilo, 14 marta, 4-5. [in Ukrainian]

Dolynska ukrainska gimnazyia oderzhala pravo pryliudnosty na shk. r. 1913/14. (1914). Dolynska ukrainska gimnazyia oderzhala pravo pryliudnosty na shk. r. 1913/14 [Dolyna Ukrainian High School got the right of publicity on the school. 1913/14.]. Dilo, 17 chervnia, 4. [in Ukrainian]

Fakhovi shkoly v Avstryi ta v Halychyni. (1912). Fakhovi shkoly v Avstryi ta v Halychyni [Professional schools in Austria and in Galicia]. Dilo, 12 tsvitnia, 7. [in Ukrainian]

Fedchyshyn, N. \& Mahsumov, T. (2019). Osvitnia diialnist v Halychyni pochatku XX st.: istoryko-pedahohichnyi analiz [The educational activity in Halychyna at the beginning of the 20th century: historical-pedagogical analysis]. Skhidnoievropeiskyi istorychnyi visnyk, 10, 66-73. doi: 10.24919/2519-058x.10.159532. [in Ukrainian]

Halytske shkilnytstvo v shk. r. 1909/10. (1910). Halytske shkilnytstvo v shk.r. 1909/10 [Galician schooling in Shk. 1909/10]. Dilo, 3 zhovtnia, 1-2 [in Ukrainian]

Hipters, Z. (2006). Ekonomichna osvita molodi v Halychyni XIX - pershoi polovyny XX stolit: teoriia, dosvid, personalii [Economic education in Galicia of the 19th - the first half of the 20th century: theories, experience, personalities]. Lviv: LBI NBU. 220 p. [in Ukrainian]

Kurylyshyn, K. (2015). Chasopys "Dilo" (Lviv, 1880 - 1939 rr.): materialy do biobibliografistyky [The Dilo newspaper) (Lviv, 1880 - 1939): materials on biobibliography] (Vol. 5: 1905 - 1909). Drogobych: Kolo, 768 p. [in Ukrainian]

Meissner, A. (2007[2008]). Edukacja miodzieïy chiopskiej w Galicji doby autonomicznej [Education of peasant youth in Galicia during the autonomous day]. Biuletyc HistoriiWychowania, 23, 21-33. [in Polish]

Miska shkola im. Markiiana Shashkevycha u Lvovi. (1913). Miska shkola im. Markiiana Shashkevycha u Lvovi [City School.Markian Shashkevich in Lviv]. Dilo, 30 serpnia, 3. [in Ukrainian] 
Na pryvatnu gimnazyiu v Drohobychy zlozhyly vid 1.XI.1911 r. do 12.VII.1913 r. Dobrodii. (1913). Na pryvatnu gimnazyiu v Drohobychy zlozhyly vid 1.XI.1911 r. do 12.VII.1913 r. Dobrodii [The private high school in Drohobych was added from 1.XI.1911 to 12.VII.1913]. Dilo, 16 lypnia, 8. [in Ukrainian]

Narodna shkola im. kn. Lva. (1914). Narodna shkola im.kn. Lva [People's School. book.The lion]. Dilo, 17 chervnia, 8. [in Ukrainian]

Nova ukrainska gimnazyia. (1912). Nova ukrainska gimnazyia [New Ukrainian high school]. Dilo, 4 veresnia, 7. [in Ukrainian]

O gimnazyiu v Chortkovi. (1911). O gimnazyiu v Chortkovi [Oh Gymnasium in Chertkov]. Dilo, 26 lypnia, 1. [in Ukrainian]

Peremyska ruska gimnazyia v shk. r. 1909/10. (1910). Peremyska ruska gimnazyia v shk. r. 1909/10 [Peremyshsk Russian Gymnasium in Shk. 1909/10] Dilo, 9 lypnia, 6. [in Ukrainian]

Persha zhinocha selianska gimnazyia v Horodentsi. (1912). Persha zhinocha selianska gimnazyia v Horodentsi [The first women's high school in Gorodenka]. Dilo, 1 chervnia, 5. [in Ukrainian]

Polska polityka v oblasty serednoho shkilnytstva. (1913). Polska polityka v oblasty serednoho shkilnytstva [Polish secondary education policy]. Dilo, 16 veresnia, 1. [in Ukrainian]

Pravo pryliudnosty. (1913). Pravo pryliudnosty [Public right]. Dilo, 9 chervnia, 5. [in Ukrainian]

Pravo pryliudnosty. (1913). Pravo pryliudnosty [Public right]. Dilo, 29 serpnia, 5. [in Ukrainian]

Pravo pryliudnosty. (1914). Pravo pryliudnosty [Public right]. Dilo, 30 maia, 5. [in Ukrainian]

Pro vyzhnytsku gimnazyiu. (1913). Pro vyzhnytsku gimnazyiu [About the High School of Exile]. Dilo, 14 maia. 6. [in Ukrainian]

Proch z utrakvizmom! (1910). Proch z utrakvizmom! [Away with the Tractivism!]. Dilo, 6 maia, 1-3. [in Ukrainian]

Proty polskoho pokhodu na nashe shkilnytstvo. (1914). Proty polskoho pokhodu na nashe shkilnytstvo [Against the Polish hike to our school]. Dilo, 14 liutoho, 1-2. [in Ukrainian]

Pryvatna ukr. gimnazyi v Busku... oderzhala pravo pryliudnosty... (1914). Pryvatna ukr. gimnazyi v Busku... oderzhala pravo pryliudnosty... [Private ukr. The high school in Busk... got the right of publicity...]. Dilo, 17 lypnia, 5. [in Ukrainian]

Pryvatnyi ukrainskyi muzheskyi uchytelskyi seminar u Lvovi. (1912). Pryvatnyi ukrainskyi muzheskyi uchytelskyi seminar u Lvovi [Private Ukrainian Men's Teacher Training Seminar in Lviv]. Dilo, 1 lypnia, 1. [in Ukrainian]

Pryvatna zhinocha semynaryia RPT v Kolomyi.(1912). Pryvatna zhinocha semynaryia RPT v Kolomyi [RPS' Private Women's Teacher Training Seminar in Kolomyia]. Dilo, 15 serpnia, 6. [in Ukrainian]

Pryvatna zhenska gimnazyia SS Vasylyianok u Lvovi v r. 1910/11. (1911). Pryvatna zhenska gimnazyia SS Vasylyianok u Lvovi v r. 1910/11 [Basilian Private Women's Seminar in Kolomyia]. Dilo, 6 lypnia, 6. [in Ukrainian]

Reorganizatsyia Ruskoho Tovarystva Pedagogichnoho. (1912). Reorganizatsyia Ruskoho Tovarystva Pedagogichnoho [Reorganization of the Russian Pedagogical Society]. Dilo, 11 lypnia, 7. [in Ukrainian]

Ruska gimnazyia v Kolomyi. (1912). Ruska gimnazyia v Kolomyi [Russian High School in Kolomyia]. Dilo, 15 serpnia, 6. [in Ukrainian]

Ruskyi Instytut dlia divchat v Peremyshly vede vid dovshykh lit zhinochyi litsei... (1910). Ruskyi Instytut dlia divchat v Peremyshly vede vid dovshykh lit zhinochyi litsei...[The Russian Institute for Girls in Przemysl has been leading women's lyceum for many years ...]. Dilo, 20 maia, 5. [in Ukrainian]

Ruskyi muzheskyi pryvatnyi seminar v Kolomyi. (1912). Ruskyi muzheskyi pryvatnyi seminar v Kolomyi [Ruttenian Men's Private Seminar in Kolomyia]. Dilo, 24 tsvitnia, 6. [in Ukrainian]

"Shkilna Pomich" u Lvovi. (1912). "Shkilna Pomich" u Lvovi ["School Help" in Lviv]. Dilo, 15 marta, 5. [in Ukrainian]

Shkola im. korolia Danyla, nova ukrainska narodna shkola na zhovkivskim peredmistiu... (1912). Shkola im. korolia Danyla, nova ukrainska narodna shkola na zhovkivskim peredmistiu... 
[King Danylo School - a new Ukrainian people's school on the outskirts of Zhukov ...]. Dilo, 26 chervnia, 5. [in Ukrainian]

Shkoly zhinochoho hospodarstva v Halychyni. (1912). Shkoly zhinochoho hospodarstva v Halychyni [School of Women's Economics in Galicia]. Dilo, 9 serpnia, 7. [in Ukrainian]

Soliar, I. \& Sholota, K. (1919).Ukrainske pytannia na konhresakh natsionalnykh menshyn u druhii polovyni 1920-kh rokiv (za materialamy chasopysu "Dilo") [Ukrainian issue at the national minorities Congresses in the second half of the 1920-ies (based on the periodical "Dilo")]. Skhidnoievropeiskyi istorychnyi visnyk, 11, 142-157. doi: 10.24919/2519-058x.11.171314. [in Ukrainian]

Slidamy Kraievoi Rady Shkilnoi. (1912). Slidamy Kraievoi Rady Shkilnoi [In the wake of the School Board]. Dilo, 30 serpnia, 2-3. [in Ukrainian].

Sprava pomyluvania obzhalovanykh $\mathbf{v}$ protsesi 101. (1912). Sprava pomyluvania obzhalovanykh $\mathrm{v}$ protsesi 101 [The case of the pardon of the complained in the process]. Dilo, 23 marta, 5. [in Ukrainian]

Stinia, M. (2010). Szkolnictwo prywatne autonomicznej Galicji: nie tylko c.k. [Private education of autonomous Galicia: not only the Imperial-Royal regime]. Wiadomości Historyczne, 2, 13-17. [in Polish]

Stuparyk, B. M. (1998). Natsionalna shkola: vytoky, stanovlennia [National school: turns, formation]. Kyiv: IZMN, 336 p. [in Ukrainian]

Stynska, V. V. (2007). Systema shkilnytstva v Halychyni (kinets XIX - pochatok XX st.) [The school system in Galicia (end of XIX-beginning of XX century)]. Ivano-Frankivsk: Hostynets, $180 \mathrm{p}$. [in Ukrainian]

Świeboda, J. (1996). Szkolnictwo ukraińskie w Galicji (1772 - 1918). Stan badac i potrzeby [Ukrainian education in Galicia $(1772$ - 1918). Research status and needs]. In Galicja i jej dzidzictwo (Vol. 8, pp. 271-291). Rzeszów: Wyd-wo WSP. [in Polish]

Ternopil (Pryv. ukr. seminar uchytelskyi). (1913). Ternopil (Pryv. ukr. seminar uchytelskyi) [Ternopil (Apprentice Ukrainian Teacher Training Seminar)]. Dilo, 16 maia, 5. [in Ukrainian]

Ts. k. derzhavna gimnazyia v Kitsmany. (1911). Ts. k. derzhavna gimnazyia v Kitsmany [Imp. Kitsman State High School]. Dilo, 11 serpnia, 7. [in Ukrainian]

Ukrainska gimnazyia v Hlynianakh. (1912). Ukrainska gimnazyia v Hlynianakh [Ukrainian High School in Glininy]. Dilo, 19 veresnia, 6. [in Ukrainian]

Ukrainska pryvatna realna gimnazyia na Bukovyni povstaie... u Vashkivtsiakh. (1912). Ukrainska pryvatna realna gimnazyia na Bukovyni povstaie... u Vashkivtsiakh [Ukrainian private real high school in Bukovina is rising ... in Vashkivtsi]. Dilo, 3 lypnia, 5. [in Ukrainian]

Ukrainska torhovelna shkola Tovarystva "Prosvita" u Lvovi. (1912). Ukrainska torhovelna shkola Tovarystva "Prosvita" u Lvovi. [Ukrainian Trade School of the Prosvita Society in Lviv]. Dilo, 28 chervnia, 7. [in Ukrainian]

Ukrainski gimnazyi na Bukovyni. (1912). Ukrainski gimnazyi na Bukovyni [Ukrainian High Schools in Bukovina]. Dilo, 1 serpnia. 6. [in Ukrainian].

Ukrainskyi kurs gimnazyialnyi v Komarni. (1912). Ukrainskyi kurs gimnazyialnyi v Komarni [Ukrainian high school course in Komarna]. Dilo, 8 serpnia, 7. [in Ukrainian]

V pryvatnii narodnii shkoli im. Borysa Hrinchenka na horodetskim peredmistiu u Lvovi... (1910). V pryvatnii narodnii shkoli im. Borysa Hrinchenka na horodetskim peredmistiu u Lvovi... [In private public school them. Borys Grinchenko on a small town in Lviv ...]. Dilo, 9 veresnia, 5. [in Ukrainian]

Viche Rusyniv mista Lvova. (1910). Viche Rusyniv mista Lvova [Vitsy Rusyns of Lviv]. Dilo, 31 sichnia. 5-6 [in Ukrainian]

Viche ukrainskoi molodizhy u Lvovi... (1910). Viche ukrainskoi molodizhy u Lvovi... [The Youth Meeting of Ukrainian Youth in Lviv ...]. Dilo, 21 maia, 4. [in Ukrainian]

Vovk, L. (2017). Borotba tovarystva "Uchytelska hromada" za rozbudovu ukrainskoho pryvatnoho shkilnytstva v Halychyni (1910 - 1914 rr.) [Struggle of the "Teacher Community" society for development of Ukrainian private schooling in Galicia (1910 - 1914)]. Skhid, 4(150), 37-39. [in Ukrainian] 
Vshekhpolskyi mord na universyteti. (1910). Vshekhpolskyi mord na universyteti [Vsehpolsky muzzle on university]. Dilo, 1 lypnia, 1-3. [in Ukrainian]

Vykhovuiuchyi muzheskyi instytut "Kobzar"... (1914). Vykhovuiuchyi muzheskyi instytut "Kobzar"... [Vihovuyuchy male institute "Kobzar" ...]. Dilo, 20 chervnia. 7. [in Ukrainian]

Vyrok polskoho sudu na ukrainskykh studentiv. (1911). Vyrok polskoho sudu na ukrainskykh studentiv [Viol of the Polish court to Ukrainian students]. Dilo, 4 lypnia, 1. [in Ukrainian]

Yak lvivska ruska hromada dbaie pro bidnu ditvoru shkoly imeny Markyiana Shashkevycha? (1910). Yak lvivska ruska hromada dbaie pro bidnu ditvoru shkoly imeny Markyiana Shashkevycha? [Yak Lvivska Ruska Gromada dba€ about the history of the school named after Markiyan Shashkevich?]. Dilo, 25 maia, 6-7. [in Ukrainian]

Z Horodenky (V spravi pryvatnoi ruskoi gimnazyi). (1910). Z Horodenky (V spravi pryvatnoi ruskoi gimnazyi) [From Gorodenki (In the reference private Russian Rusimnazy)]. Dilo, 6 maia, 5. [in Ukrainian]

Z Pokutia (Korshivska fakhova shkola i "Silskyi Hospodar"). (1914). Z Pokutia (Korshivska fakhova shkola i "Silskyi Hospodar"). [Z Pokutya (Korshivska Fakhova School I "Silsky Gospodar")]. Dilo, 26 liutoho, 7. [in Ukrainian]

Za ukrainskyi universytet. (1912). Za ukrainskyi universytet [For Ukrainian University]. Dilo, 1 lypnia. 2-3. [in Ukrainian]

Zaviazanie "fondu sotykovoho" u Lvovi. (1911). Zaviazanie "fondu sotykovoho" u Lvovi [Setting up a "cellular fund" in Lviv]. Dilo, 4 sichnia. 6. [in Ukrainian]

The article was received on April 20, 2020. Article recommended for publishing 26/11/2020. 